\title{
TGF- $\beta$ polymorphism and its expression correlated with CXCR4 expression in human breast cancer
}

\author{
Julie Massayo Maeda Oda ${ }^{1 *}$, Karen Brajão de Oliveira ${ }^{1}$, Roberta Losi Guembarovski ${ }^{1}$, Alda Losi Guembarovski ${ }^{2}$, \\ Glauco Akelinghton Freire Vitiello', Patricia Midori Murobushi Ozawa', Bruna Karina Banin Hirata', \\ Vânia Darc de Castro ${ }^{1}$, Maria Angelica Ehara Watanabe ${ }^{1}$
}

From São Paulo Advanced School of Comparative Oncology

Águas de São Pedro, Brazil. 30 September - 6 October 2012

\section{Background}

It is known that the transforming growth factor beta (TGF- $\beta$ ) can act as both a tumor suppressor and as a significant stimulator of tumor progression, invasion, and metastasis. It has been suggested a link between TGF- $\beta$ and CXCR4 expression in human breast cancer cells, which may be one of the mechanisms of TGF- $\beta$ mediated enhancement of metastatic potential in breast cancer cells. Therefore, the objective of the present study was to investigate the TGF- $\beta$ T 869 C polymorphism and its expression correlated with CXCR4 expression in breast cancer patients.

\section{Patients and methods}

Genomic DNA was obtained from 21 samples of peripheral blood or from normal tissue previously fixed in formalin and embedded in paraffin for TGF- $\beta$ T869C polymorphism analyses. Total cellular RNA was extracted from the same 21 patients, but from fresh tissue (tumor and adjacent healthy from the same breast) to expression analysis by Real Time PCR.

\section{Results}

No significant differences were observed in genotype distribution according to clinic pathological characteristics. TGF- $\beta$ mRNA expression was assessed according to T869C polymorphism and CC patients presented a higher TGF- $\beta$ expression but not significant when compared to other genotypes $(\mathrm{p}=0.064)$. A positive correlation was observed in relative mRNA expressions of CXCR4 and TGF- $\beta(p=0.020)$. It is known that overexpression of TGF- $\beta$ by both tumor and stromal tissue can facilitate the development of metastases, mainly by TGF- $\beta$ stimulated angiogenesis and increased tumor cell motility.

\section{Conclusion}

Our findings suggested a role of these genes as progression markers for breast carcinoma.

\section{Financial support}

CNPq, CAPES, Fundação Araucaria and PROPPG-UEL.

\section{Author details}

'Department of Pathological Sciences, Biological Sciences Center, State University of Londrina, Londrina, PR, Brazil. 'Laboratory of Pathology, Healthy Sciences Center, State University of Londrina and Laboratory of Applied Pathology, MICROPAR, Londrina, PR, Brazil.

Published: 4 April 2013

doi:10.1186/1753-6561-7-S2-P38

Cite this article as: Oda et al: TGF- $\beta$ polymorphism and its expression

correlated with CXCR4 expression in human breast cancer. BMC Proceedings 2013 7(Suppl 2):P38.

\footnotetext{
* Correspondence: julie_massayo@hotmail.com

'Department of Pathological Sciences, Biological Sciences Center, State

University of Londrina, Londrina, PR, Brazil

Full list of author information is available at the end of the article
}

(C) 2013 Oda et al; licensee BioMed Central Ltd. This is an Open Access article distributed under the terms of the Creative Commons 